\title{
Selection justification of methods for obtaining glass-ceramic materials
}

\author{
O.V. Savvova ${ }^{1}$ (0000-0001-6664-2274), S.A. Ryabinin ${ }^{2}$ (0000-0003-2972-8540), E.A. Svitlichniy3, \\ G.K. Voronov ${ }^{2}$ (0000-0003-1205-8608), A.I. Fesenko² (0000-0003-3888-9493) \\ ${ }^{1}$ O.M. Beketov National University of Urban Economy in Kharkiv, 17, st. Marshal Bazhanov, Kharkiv, 61002, Ukraine \\ Tel. +380577073101 \\ E-mail: savvova_oksana@ukr.net \\ ${ }^{2}$ National Technical University «Kharkiv Polytechnic Institute», 2, st. Kirpicheva, Kharkiv, 61002, Ukraine \\ Tel. +380577076600 \\ E-mail: riabinin_svytoslav@hotmail.com \\ ${ }^{3}$ National Science Center "Kharkov Institute of Physics and Technology”, 61108, Ukraine, Kharkiv, st. Academic, 1 \\ Tel. +380573353530 \\ E-mail: SvitlichnyYO1976@nas.gov.ua
}

Article info: received 28.06.2019, revised 19.07.2019, accepted 27.08.2019

Savvova, A.V., Ryabinin, S.A., Svetlichny, E.A., Voronov, G.K., Fesenko, A.I. (2019) Selection justification of the choice of methods for obtaining glass-ceramic materials 3(44), doi: 10.26909/csl.3.2019.1

Advanced methods for obtaining high-strength glass-ceramic materials based on lithium aluminum silicate glass for glass and ceramic technologies are identified. Were analyzed forming methods: pressing, thermoplastic molding and slip casting with the definition the advantages and disadvantages of in each of them. The choice of the base LAS system is substantiated and model lithium-aluminum-silicate glasses and glass-ceramic materials based on $\beta$-spodumene are synthesized by the methods of pressing, slip casting and thermoplastic molding. The features of the formation of glass-ceramic materials using various technologies are investigated.

Technological parameters were established for pressing: molding powder with a fraction size from 63 to $125 \mu \mathrm{m}-70$ vol. \%, from 25 to 63 microns -15 vol. $\%$, less 25 microns -15 vol. \%, xanthan gum solution in an amount of 10 wt. \%; for slip casting: slip specific weight $-\gamma=1852 \mathrm{~kg} / \mathrm{m}^{3}, \mathrm{pH}=9.90$; for the thermoplastic formation: paraffin -15 wt. $\%$, beeswax -5 wt. $\%$, oleic acid -1 wt. $\%$. It has been established that the determining influence on the mechanical properties of the developed glass-ceramic materials has the character of their micro- and macrostructures. It has been established that, for the studied glass-ceramic materials, an increase in porosity and pore size significantly affects the magnitude of their compressive strength.

Glass-ceramic materials obtained by wet pressing and slip technology can be recommended as the most technologically advanced in creating composite armor elements and promising in the development of high-strength glass-ceramic materials for the local protection of special equipment and technology.

Composite structural materials obtained by thermoplastic processing can be used to create high-strength parts for precision mechanisms and instruments, which are subject to stringent requirements for mechanical strength.

Key words: glass-ceramic materials, lithium aluminum silicate glass, technological parameters.

\section{Обгрунтування вибору методів одержання склокерамічних матеріалів}

\author{
О.В. Саввова ${ }^{1}$, С.О. Рябінін ${ }^{2}$, С.О. Світличний ${ }^{3}$, Г.К. Воронов ${ }^{2}$ О.І. Фесенко ${ }^{2}$ \\ ${ }^{1}$ Харківський національний університет міського господарства ім. О.М. Бекетова, Харків, Украйна \\ ${ }^{2}$ Національний технічний університет «Харківський політехнічний інститут», Харків, Україна \\ ${ }^{3}$ Національний науковий центтр «Харківський фізико-технічний інститут», Харків, Украӥна
}

Визначені перспективні методи отримання високоміцних склокерамічних матеріалів на основі літійалюмосилікатних стекол за скляною та керамічною технологіями. Проведено порівняльний аналіз методів пресування, термопластичного формування та шлікерного лиття з визначенням переваг та недоліків у кожному 3 них. Обгрунтовано вибір базової системи LAS та синтезовано модельні літійалюмосилікатні стекла та склокерамічні 
матеріали на основі $\beta$-сподумену за методами пресування, шлікерного лиття та термопластичного формування. Досліджено особливості формування склокерамічних матеріалів за різними технологіями.

Встановлено технологічні параметри для пресування: порошок для пресування 3 розміром фракцій $63-125$ мкм $\approx 70$ об. \%, 25 - 63 мкм - 15 об. \%, менше 25 мкм - 15 об. \%, розчин ксантанової камеді в кількості 10 мас.; для шлікерного лиття: питома вага шлікеру $-\gamma=1852$ кг $/ \mathrm{m}^{3}, \mathrm{pH}=9,90$; для термопластичного формування: парафіну - 15 мас. \%, бджолиного воску - 5 мас. \% та олеїнової кислоти - 1 мас. \%. Встановлено, що визначальний вплив на механічні властивості розроблених склокерамічних матеріалів має характер їх мікро- та макроструктури. Визначено що для дослідних склокерамічних матеріалів збільшення пористості та розмір пор суттєво позначаються на величині їх міцності на стиск.

Склокерамічні матеріали, отримані методом вологого пресування та за шлікерною технологією, можуть бути рекомендовані, як найбільш технологічні, при створенні композиційних бронеелементів та є перспективними при розробці високоміцних склокерамічних матеріалів для локального захисту спеціальної техніки та обладнання.

Композиційні конструкційні матеріали, що отримані за технологією термопластичного формування, можуть бути використані для створення високоміцних деталей прецизійних механізмів та приладів, до яких встановлюються жорсткі вимоги до механічної міцності.

\section{Вступ}

На сьогодні велика увага приділяється пошуку нових матеріалів, що будуть відповідати зростаючим вимогам науки та техніки. Поєднання високих фізико-хімічних та технологічних характеристик дозволяють використовувати склокерамічні матеріали як матеріали в галузях промисловості: енергетичній (сонячні панелі, частини електронних компонентів, ізоляторів, теплоелектричні генератори, композиції для іммобілізації ядерних відходів), аерокосмічній (обтікачі літальних апаратів, теплоізоляційні та термостійкі матеріали), будівельній (матеріали з протигрибковими і самоочисними властивостями, матеріали 3 динамічними здібностями зміни кольору), військовій (елементи бронезахисту, та обладнання); хімічній (лабораторний посуд, складові обладнання), електроніці (підкладки мікросхем, нанопокриття і нанолітографія в високотехнологічних матеріалах) та побуті (кухонний посуд, панелі плит) [1].

Зростаючі вимоги до експлуатаційних властивостей матеріалів, що експлуатуються в умовах значних динамічних навантажень, вказують на необхідність створення надійних ефективних захисних матеріалів. На сьогодні відомі високоміцні склокерамічні матеріали на основі $\beta$-сподумену, що характеризуються високими термічними та механічними властивостями [2]. Однак їх використання як ударостійких матеріалів обмежується достатньо високими температурами варки та тривалістю термічної обробки.

Одним 3 ефективних рішень цієї проблеми $є$ створення нового виду матеріалів - технологічних високоміцних склокерамічних матеріалів (СКМ) 3 підвищеними показниками механічної стійкості та зниженою вагою в умовах низькотемпературної термообробки. Їх розробка дозволить в найкоротший термін отримати конструкційні елементи, які змо- жуть задовольнити потреби промисловості в ефективних високоміцних матеріалах.

Важливим фактором забезпечення високих експлуатаційних властивостей склокерамічних матеріалів $є$ оптимальний вибір технологічних параметрів їх одержання, зокрема, методів їх формування.

Для вибору технології отримання монолітних виробів зі склокераміки було проведено аналіз існуючих методів формування склокерамічних матеріалів $[3,4]$. На сьогоднішній день використовується два основних метода формування заготовки зі склокераміки: за скляною (лиття з розплаву, пресування, відцентрове лиття) та керамічною технологією (з водних шлікерів, пресування, термопластичне формування).

Перший метод передбачає формування монолітних заготовок (виробів) методом лиття склорозплаву в металеві форми та подальшою їх термообробкою послідовно при температурі зародкоутворення та при верхній температурі кристалізації, що призводить до ситалізації зразків по всьому об'єму виробу. Треба відзначити складність даної технології отримання стекол сподуменового складу, зокрема, високу температуру варки скла та реакційну здатність склорозплаву до вогнетривів. Неякісний провар скла може призвести до наявності у склокерамічному матеріалі різних недоліків (непроварів, бульбашок та ін.), які спричиняють локальні неоднорідності властивостей виробу та істотно ускладнюють їх використання. На практиці формування виробів пов'язане з великими труднощами: розплав характеризується досить коротким і вузьким температурним інтервалом формування, який зміщений в область підвищених температур. У зв'язку з цим найчастіше при формуванні ситалів застосовують лиття, зокрема відцентрове, і пресування [5]. Однак до недоліків даного методу треба віднести складність виготовлення склокерамічних виробів об'ємної та багатопрофільної конфігурації. 
Альтернативним методом формування монолітних склокерамічних виробів, у тому числі виробів складної конфігурації, $є$ виготовлення за другим методом - керамічними технологіями: шляхом пресування з порошків зі зв'язкою, водного шлікерного лиття в гіпсові форми [6] та термопластичного формування [7].

Так, виходячи 3 кінетики формування матеріалів і заготовки в рамках методу шлікерного лиття, можна виділити три варіанти, які принципово відрізняються один від одного як за технологічністю, так і за властивостями вихідної та термообробленої заготовки.

Перший варіант передбачає лиття виробів 3 низькощільних ( $\left.\rho=1740-1800 \kappa \Gamma / \mathrm{M}^{3}\right)$ седиментаційно нестійких шлікерів 3 вологістю суспензій $15-23 \%$, де набір маси матеріалу і заготовки здійснюється в основному за рахунок гравітаційного осадження часток шлікеру в форму. Це дозволяє формувати товстостінні вироби складного профілю.

За другим варіантом до шлікеру з вищезазначеною щільністю вводять зернистий наповнювач, зокрема, у вигляді порошку кварцового скла, до отримання щільності не нижче 1940 кг/м³. Висока щільність і в'язкість суспензій перешкоджають їх розшаруванню при формуванні крупногабаритних виробів і створюють умови для одержання однорідної заготовки зі значною різнотовщинністю. Формування матеріалу і заготовки здійснюється в основному за рахунок в'яжучих властивостей кварцової суспензії і твердіння маси у формі при частковому поглинанні води гіпсом. Недоліком даного способу є також те, що цим способом неможливо виготовити невеликі керамічні вироби складної форми [8].

Формування матеріалу за третім варіантом здійснюється 3 середньощільних шлікерів $\left(\rho=1860-1920 \kappa г / \mathrm{M}^{3}\right)$ та за сутністю полягає у наборі заготовки на поверхні гіпсової форми за рахунок капілярних властивостей гіпсу. Отриманий матеріал має високу упаковку часток шлікеру і найвищу міцність матеріалів на згин серед методів шлікерного лиття. Необхідно при цьому зазначити, що вказаний спосіб прийнятий тільки для формування рівнотовщинних тонкостінних виробів і не придатний для отримання товстостінних й різнотовщинних заготовок.

Альтернативою шлікерному литтю у гіпсові форми $є$ термопластичне формування. Для формування виробів використовується відливка під тиском з термопластичних суспензій в парафіні з олеїновою кислотою. Даний метод дозволяє отримувати відливки складного профілю без необхідності проміжної сушки та дозволяє одразу після формування проводити термообробку склокерамічного матеріалу [7].
Найбільш технологічним є спосіб отримання виробів шляхом пресування. Особливістю способу $є$ те, що до скляних порошків, які не мають в'яжучої спроможності, при вологому пресуванні додають $2 \div 5$ мас. \% ксантанової камеді. Використовується як одностадійне так і багатостадійне пресування виробів. Це дозволяє отримувати матеріали з різною щільністю та міцністю. Найбільш міцні вироби отримуються шляхом багатостадійного пресування 3 поступовим збільшенням величини стискаючого зусилля. Даний метод дає можливість отримати вироби простої форми.

Порівняльний аналіз технологій та методів формування (табл. 1) дозволив встановити, що для одержання високоміцних склокерамічних матеріалів найперспективнішими $є$ методи отримання за керамічною технологією, оскільки дають можливість отримання різнопрофільних та різнотовщинних виробів. Тому пошук оптимальних методів одержання високоміцних склокерамічних матеріалів, які експлуатуються в умовах підвищених динамічних навантажень, є актуальною задачею.

\section{Мета роботи}

Метою роботи є обгрунтування методів формування та визначення оптимальних технологічних параметрів отримання високоміцних склокерамічних матеріалів на основі літійалюмосилікатної склокераміки в умовах низькотемпературної короткотривалої термічної обробки.

\section{Матеріали та методи дослідження}

Для виготовлення зразків методом пресування та шлікерного лиття помел стекол проводили у планетарному млині Retsch PM-400. Для пресування зразків використовували лабораторний гідравлічний прес з максимальним навантаженням $\mathrm{P}=24,5$ МПа.

Особливістю термопластичного формування $\epsilon$ готування шлікерів у лабораторному інжекторі шляхом додавання до скла парафіну, воску та олеїнової кислоти. Схема лабораторного інжектору показана на рис. 1.

Основою роботи інжектору $\epsilon$ застосування термостатичної камери та використання тиску стислого повітря для переміщення шлікеру у форму. Термостатична камера складається із металевого резервуару для шлікеру (1) 3 кришкою (3), до якої приварено штуцер для подачі повітря (6); а також живильника (7); нагрівача, у якості якого є ніхромова спіраль (2) та терморегулятору (8), що підтримує робочу температуру.

Дослідження структури зразків проводилось на оптичному мікроскопі Bresser LCD Micro 40x-1600x. 
ISSN 2521-6694 (Print) Ceramics: science and life, 3(44), 2019

Таблиця 1.

Технології та методи формування склокерамічних матеріалів

\begin{tabular}{|c|c|c|c|}
\hline \multicolumn{2}{|c|}{$\begin{array}{r}\text { Методи } \\
\text { Тормування }\end{array}$} & Переваги & Недоліки \\
\hline \multirow{3}{*}{ 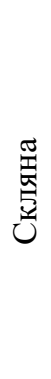 } & Відливка у форми & \multirow{3}{*}{$\begin{array}{c}\text { Отримання монолітних виробів } \\
\text { відразу після варки скла }\end{array}$} & $\begin{array}{c}\text { Можливе розтріскування скла } \\
\text { та розшаровування, складність } \\
\text { отримання бездефектних виробів }\end{array}$ \\
\hline & Гаряче пресування & & $\begin{array}{c}\text { Залишки слідів на поверхні, важкість } \\
\text { наступної механічної обробки }\end{array}$ \\
\hline & Відцентрове лиття & & $\begin{array}{l}\text { Неможливість отримання } \\
\text { об’ємних виробів }\end{array}$ \\
\hline \multirow{3}{*}{ 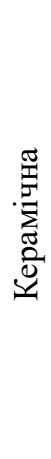 } & Пресування & $\begin{array}{c}\text { Отримання виробів } 3 \text { простою } \\
\text { поверхнею }\end{array}$ & $\begin{array}{c}\text { Неможливість отримання } \\
\text { об’ємних та порожнистих виробів }\end{array}$ \\
\hline & $\begin{array}{l}\text { Шлікерне лиття } \\
\text { Низькощільні шлікери } \\
\text { Високощільні шлікери } \\
\text { Середньощільні шлікери }\end{array}$ & $\begin{array}{c}\text { Отримання виробів: } \\
\text { товстостінних складного профілю; } \\
\text { однорідних зі значною } \\
\text { різнотовщинністю; } \\
\text { рівнотовщинних тонкостінних }\end{array}$ & $\begin{array}{c}\text { Багатостадійнісь, довготривалість } \\
\text { процесу формування, складність } \\
\text { вилучення виробу з гіпсової форми }\end{array}$ \\
\hline & $\begin{array}{l}\text { Термопластичне } \\
\text { формування }\end{array}$ & $\begin{array}{l}\text { Отримання виробів } \\
\text { складного профілю }\end{array}$ & $\begin{array}{c}\text { Довготривалість підготовки матеріалу } \\
\text { до формування, необхідність випалу } \\
\text { для видалення зв’язки }\end{array}$ \\
\hline
\end{tabular}

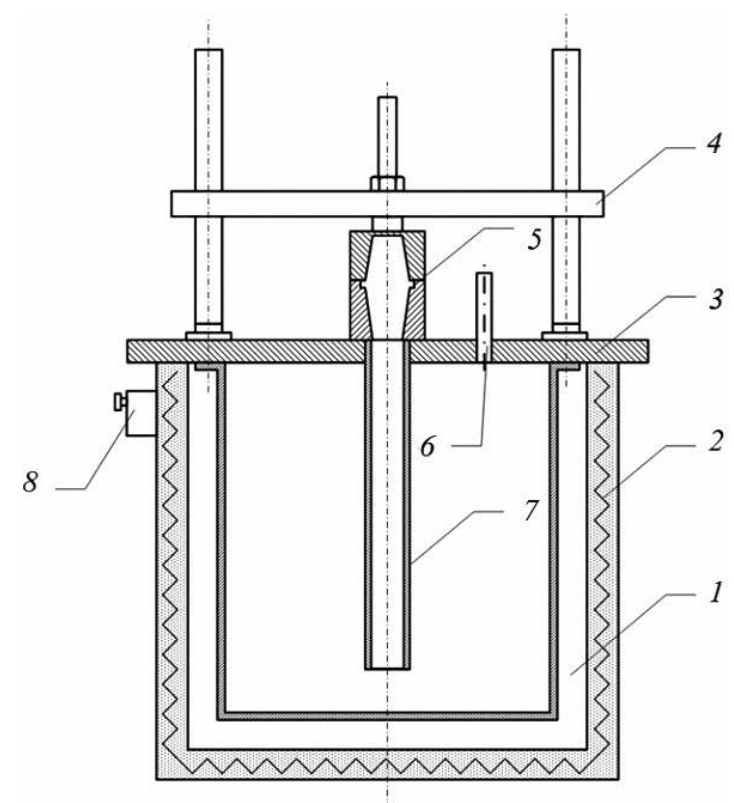

Рис. 1. Схема лабораторного інжектору

1 - резервуар для шлікеру; 2 - ніхромова спіраль; 3 - кришка (робочий стіл); 4 - прижимний устрій; 5 - форма; 6 - штуцер для подачі повітря; 7 - живильник; 8 - терморегулятор 
Пористість визначали методом гідростатичного зважування з використанням установки для насичування зразків рідиною у вакуумі. Визначення дійсної щільності отриманих матеріалів здійснювали пікнометричним методом за ГОСТ 2211-65; уявну щільність та відкриту пористість встановлювали за ГОСТ 2409-95 (ISO 5017-88).

Мікротвердість $H$ та твердість за Віккерсом $H V$ і показник тріщиностійкості (в'язкість руйнування) $K_{l C}$ визначали шляхом вдавлювання піраміди Віккерса при навантаженні на піраміду відповідно 200 г за 10 вимірами та 5000 г за 5 вимірами з використанням приладів ПМТ-3 і ТМВ-1000. Ударну в'язкість (KCU) визначали за ГОСТ (GOST)110672013 (EN1288-1:2000).

\section{Результати та їх обговорення}

За результатами попередніх досліджень особливостей складу та структури літійалюмосилікатних склокерамічних матеріалів у зв'язку 3 їх міцносними властивостями [10] було модифіковано скло СП-9 та отримано скло СП-10, яке додатково вміщує $\mathrm{TiO}_{2}, \mathrm{CaO}, \mathrm{K}_{2} \mathrm{O}, \mathrm{ZrO}_{2}, \mathrm{SnO}_{2}$ (табл. 2) для забезпечення високої структурної міцності.

Для виготовлення шихти при синтезі скла використовували природну мінеральну сировину (пісок Новоселівський, глинозем, циркон, крейда, калієвий польовий шпат), оксиди маркування ХЧ $(\mathrm{ZnO}$, $\mathrm{TiO}_{2}, \mathrm{CeO}_{2}, \mathrm{MgO}, \mathrm{SnO}_{2}, \mathrm{MnO}_{2}$ ) та інші хімічні сполуки (вуглекислий літій, борна кислота, амоній фосфорнокислий однозаміщений).

Варку стекол серій СП здійснювали у корундових тиглях в лабораторній електричній печі при температурах $1350{ }^{\circ} \mathrm{C}$ впродовж 6 годин 3 наступним виливанням на металеву пластину.

Склокерамічні матеріали отримували шляхом двостадійної термічної обробки: 1 стадія - витрим- ка при $530{ }^{\circ} \mathrm{C}$ впродовж двох год. та 2 стадія - при $850{ }^{\circ} \mathrm{C}$ впродовж двох год.

Після двостадійної термічної обробки склокерамічний матеріал СП-10, який отримано за скляною технологією, характеризується об'ємною тонкодисперсною кристалізацією високоміцної кристалічної фази $\beta$-сподумену у кількості 80 об. \%.

Для одержання бездефектних СКМ було розроблено технологічні параметри формування за різними методами керамічної технології.

Пресування. Вихідне скло СП-10 було подрібнено до повного проходження крізь сита: № 125 з розміром фракцій 63 - 125 мкм $\approx 70$ об. \%, № $063-63$ - 25 мкм - 15 об. \%, № 025 не більше 25 мкм - 15 об. \%. Розмір фракцій та їх співвідношення були обрані 3 урахуванням даних щодо забезпечення високої щільності упаковки матеріалів [9]. В якості зв'язки було використано розчин ксантанової камеді в кількості 10 мас. \%. Проведено тристадійне пресування маси матеріалу в гідравлічному пресі з тиском на 1 стадії - 7,36 МПа, 2 стадії - 11,78 МПа, 3 стадії - 14,71 МПа. Відпресовані матеріали з маркуванням СП-10П сушаться при температурі $120 \div 150^{\circ} \mathrm{C}$ до остаточної вологості не більш 0,5 \%, з наступною двостадійною короткотривалою термічною обробкою.

Шлікерне лиття. Виходячи 3 необхідності отримання товстостінних виробів, зокрема й складної конфігурації, за керамічною технологією було здійснено варку скла та двостадійний мокрий помел фрити при наступних параметрах:

- швидкість обертання барабану 110 об./хв;

- співвідношення фрити до млинних тіл 1 : 3 ;

- кількість води 30 мас. \%;

- ступінь заповнення об'єму млину 50 \%;

- форма млинних тіл - сферична; матеріал млинних тіл - алюбіт;

- розмір млинних тіл - 5, 10, 15 мм та їх співвідношення за вагою $1: 1: 1$.

Таблиця 2.

Хімічний склад модельних стекол серії СП та характеристика кристалічних фаз

\begin{tabular}{|c|c|c|c|c|c|c|c|c|c|}
\hline \multirow{3}{*}{ 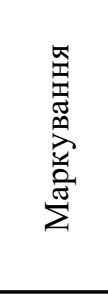 } & \multicolumn{9}{|c|}{ Відмінності за хімічним складом, мас. \% } \\
\hline & \multirow{2}{*}{$\begin{array}{c}\sum \mathrm{Li}_{2} \mathrm{O} \\
\mathrm{K}_{2} \mathrm{O}\end{array}$} & \multirow{2}{*}{$\begin{array}{c}\sum \mathrm{Al}_{2} \mathrm{O}_{3}, \\
\mathrm{~B}_{2} \mathrm{O}_{3}\end{array}$} & \multirow[t]{2}{*}{$\mathrm{SiO}_{2}$} & \multirow{2}{*}{$\begin{array}{c}\sum \mathrm{CaO} \\
\mathrm{MgO} \\
\mathrm{ZnO}\end{array}$} & \multirow[t]{2}{*}{$\mathrm{P}_{2} \mathrm{O}_{5}$} & \multirow{2}{*}{$\begin{array}{c}\sum \mathrm{TiO}_{2}, \\
\mathrm{ZrO}_{2}, \\
\mathrm{SnO}_{2} \\
\mathrm{MnO}_{2}, \\
\mathrm{CeO}_{2}\end{array}$} & \multirow{2}{*}{$\begin{array}{l}\text { Темпе- } \\
\text { ратура } \\
\text { варіння }\end{array}$} & \multicolumn{2}{|c|}{ Структура стекол } \\
\hline & & & & & & & & $\begin{array}{c}\text { Після } \\
\text { варіння }\end{array}$ & $\begin{array}{c}\text { Після } \\
\text { термічної } \\
\text { обробки }\end{array}$ \\
\hline СП-9 & 8,0 & 21,5 & 60,0 & 5,0 & 3,0 & 2,5 & 1350 & \multirow{2}{*}{ Аморфна } & \multirow{2}{*}{$\beta-\mathrm{LiAlSi}_{2} \mathrm{O}_{6}$} \\
\hline СП-10 & 9,0 & 19,5 & 60,0 & 4,0 & 3,0 & 6,5 & 1350 & & \\
\hline
\end{tabular}


3 метою попередження злипання дрібних часток, забезпечення плинності шлікерів, а також прискорення процесу помелу до млину було введено добавку дефлокулянту Dolapix FF6 у кількості 0,5 мас. $\%$.

Після 2 год. помелу було одержано водні шлікери 3 наступними технологічними параметрами:

- питома вага $\rho=1852 \kappa г / \mathrm{M}^{3}$;

- $\mathrm{pH}=9,90$;

- тонини помелу дисперсної склофази з залишком на ситі №0063 3 - 5 \%.

Після завершення помелу шлікер відокремлювали від млинних тіл, проціджували через сітку з розміром комірки 1 мм і переливали в ємність для старіння. Стабілізацію шлікеру проводили механічним перемішуванням 3 подальшим додаванням $\mathrm{HCl}$ або $\mathrm{NH}_{4} \mathrm{Cl}$ в кількості 1,0 - 2,0 мл на 1 л шлікеру [10].

Шлікер перемішують впродовж не менше 24 годин. Механічне перемішування практично не змінює зернового складу і вологості шлікеру, але сприяє дегазації суспензії, підвищує щільність і міцність відливки, покращує седиментаційну стійкість суспензї і сприяє однорідності заготовки. Шлікер після старіння проціджували через сито 0,5 мм і вимірювали його властивості, зокрема $\mathrm{pH}$, який склав 9,45.

Формування виробів проводили методом шлікерного лиття у гіпсові форми. Готові відливки сушаться при температурі $120 \div 150{ }^{\circ} \mathrm{C}$ до остаточної вологості виробів не більш $0,5 \%$. Після сушіння сформовані вироби на основі матеріалу з маркуванням СП-10Ш підлягають термообробці в електричній печі.

Термопластичне формування. Порошок скла СП-10 після повного проходження через сито №0063 змішували 3 олеїновою кислотою протягом двох годин, кількість якої варіювався в межах $0,2 \div 1,0$ мас. $\%$, після чого готували термопластичні суспензії із застосуванням зв'язки на основі парафіну і воску. Мінімальний вміст зв'язки в залежності від кількості кислоти становить $12 \div 16$ мас. \%. Було встановлено, що термопластичні суспензії мають певну межу плинності. При цьому суспензії 3 вмістом $0,7 \div 1,0$ мас. \% олеїнової кислоти характеризуються найбільшою плинністю при рівному вмісті зв'язки. Таким чином, гарячий шлікер 3 робочою температурою $70 \div 100{ }^{\circ} \mathrm{C}$, що отриманий в термостатичній камері, завдяки використанню стислого повітря та живильника подається в металеву форму виробу та охолоджується у вигляді зразків різної конфігурації.

Оскільки шлікери на основі порошків усіх складів, що виготовлені при температурі $<70^{\circ} \mathrm{C}$, мають незадовільну текучість, а шлікери з температурою $\geq$ $90{ }^{\circ} \mathrm{C}$ мають велику кількість газових включень, то формування зразків проводили в інтервалі температур $70 \div 80^{\circ} \mathrm{C}$. Отримані за методом термопластичного формування відливки різної форми випалювали в електропечі при температурі $530{ }^{\circ} \mathrm{C}$ з засипкою порошком $\mathrm{Al}_{2} \mathrm{O}_{3}$ для поглинання залишкової зв'язки впродовж 2 год., а потім проводили термообробку зразків матеріалів 3 маркуванням СП-10Т при температурі $850^{\circ} \mathrm{C}$ впродовж 2 год. Експериментальним шляхом було визначено, що оптимальним для отримання бездефектних СКМ є склад шлікеру в якому вміст парафіну складає 15 мас. \%, бджолиного воску - 5 мас. \% та олеїнової кислоти -1 мас. \%. Зовнішній вигляд зразків отриманих за різними методами формування наведено на рис. 2 .
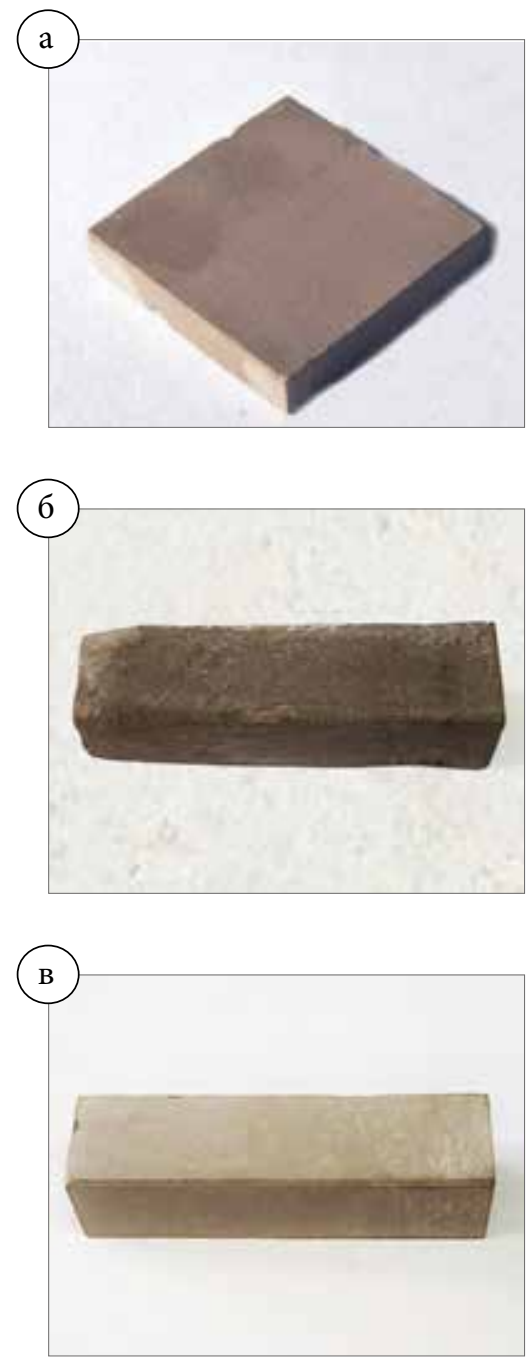

Рис. 2. Зовнішній вигляд зразків СП-10П, СП-10Ш та СП-10Т відповідно, отриманих за методом: а) пресування, б) шлікерного лиття, в) термопластичного формування 
Після двостадійної термічної обробки дослідні зразки СП-10П, СП-10Ш та СП-10Т, які отримано за різними методами формування: пресування, шлікерне лиття та термопластичне формування відповідно, характеризувалися ситалізованою структурою з вмістом кристалічної фази $\approx 80$ об. \%. Однак їх структурні характеристики, зокрема, пористість значно відрізнялися. Так, практично нульовою відкритою та закритою пористістю (табл. 3) характеризувалися зразки отримані за шлікерною технологією формування. Зразки отримані методом пресування та пластичного формування мають незначну закриту пористість $\approx 5 \div 10 \%$ завдяки оплавленню скло фази, яка заліковує тріщини і пори розміром $\approx 0,1$ мкм та проростанню кристалів у пори зразків при термічній обробці.

Розроблені матеріали, які сформовані за різними технологіями, несуттєво відрізняються $K_{l C}$ та $H V$. Однак $з$ врахуванням складності технології та різниці у $\sigma_{\text {ст }}$ їх можна рекомендувати як високоміцні СКМ різного призначення.

Для дослідних склокерамічних матеріалів, при їх формуванні за різними методами, збільшення пористості та розмір пор суттєво позначаються на їх міцності на стиск. Найвищими значеннями механічних властивостей характеризується матеріал СП-10Ш, який має практично нульову пористість та найменший розмір пор. Підвищення міцності на стиснення до 820 ГПа для даного матеріалу дозволить використовувати його при виготовленні елементів броне захисту, в якості шару який має демпферні властивості та руйнує осердя кулі [13].

Склокерамічні матеріали отримані за методом пресування можуть бути використані в якості елементів бронезахисту, та для виготовлення плиток та деталей простого профілю.

Отримані склокерамічні матеріали за шлікерною технологією можуть бути рекомендовані при створенні композиційних бронеелементів, матеріалів для локального захисту спеціальної техніки та обладнання і в тому разі, коли потрібно виготовлення порожнистих елементів.

Отримані за технологією термопластичного формування композиційні конструкційні матеріа-

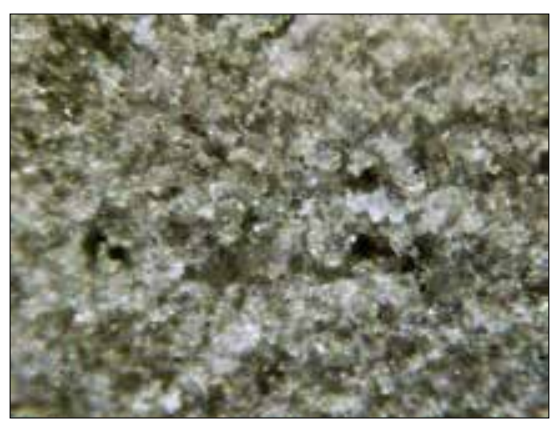

(a)

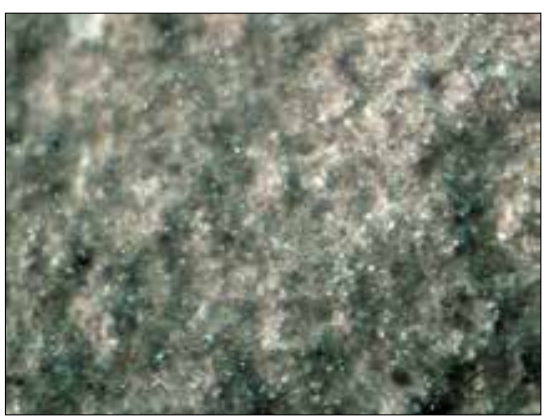

(6)

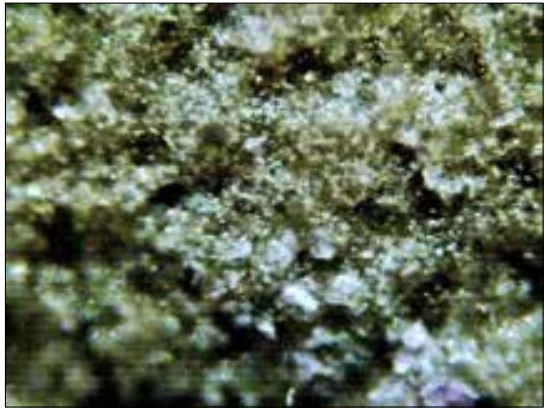

(B)

Рис. 3. Зовнішній вигляд поверхні зразків за методом пресування (а), шлікерного лиття (б), термопластичного формування (в)

Таблиця 3.

Механічні параметри отриманих зразків за різними технологіями

\begin{tabular}{|c|c|c|c|c|c|c|}
\hline Зразок & 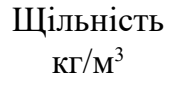 & $\begin{array}{c}\text { Відкрита } \\
\text { пористість, \% }\end{array}$ & $\begin{array}{c}\text { Закрита } \\
\text { пористість, \% }\end{array}$ & $K_{I C}, \mathrm{M \Pi а} \cdot \mathrm{M}^{0,5}$ & $H V$, ГПа & $\sigma_{\text {ст }} \Gamma \Pi а$ \\
\hline СП-10П & 2304 & 5 & 7 & 3,40 & 8,90 & 750 \\
\hline СП-10Т & 2465 & 0 & 5 & 3,5 & 9,2 & 800 \\
\hline СП-10Ш & 2563 & 0 & 1 & 3,5 & 9,2 & 820 \\
\hline
\end{tabular}


ли є перспективними при створенні високоміцних деталей прецизійних механізмів і приладів, які можливо виготовляти шляхом екструзії та до яких встановлюються жорсткі вимоги до механічної міцності та неможливо отримати методом шлікерного лиття.

\section{Висновки}

Встановлено перспективність створення високоміцних склокерамічних матеріалів на основі літійалюмосилікатної системи. Визначено особливості формування склокерамічних матеріалів за різними технологіями. Розроблено склокерамічні матеріали на основі $\beta$-сподумену за методами пресування, шлікерного лиття та термопластичного формування. Досліджено вплив структури розроблених склокерамічних матеріалів на їх механічні властивості. Встановлено, що для розроблених склокерамічних матеріалів розмір пор впливає значно на міцність, на стиск та залежить від їх мікро та макроструктури.

Встановлено технологічні параметри для пресування (розміром фракцій $63-125$ мкм $\approx 70$ об. \%, 25 - 63 мкм - 15 об. \%, не більше 25 мкм - 15 об. \%; тиском пресування на 1 стадії - 7,36 МПа, 2 стадії 11,78 МПа, 3 стадії - 14,71 МПа), шлікерного лиття

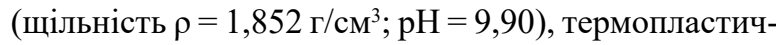
ного формування (парафін 15 мас. \%, бджолиного воску - 5 мас. \% та олеїнової кислоти -1 мас. \%), які дозволять отримати бездефектні вироби.

Розроблені склокерамічні матеріали є перспективними для використання в якості елементів для бронезахисту, та в залежності від методів формування можуть використовуватися в різних галузях цивільної та військової промисловості.

\section{References}

1. Maziar Montazerian, Shiv Prakash Singh, Edgar Dutra Zanotto. An analysis of glass-ceramic research and commercialization / American Ceramic Society Bulletin. - 2015. - Vol. 94. - No. 4. - P. 30 - 35.

2. Брагіна, Л.Л. Структура та властивості склокристалічних матеріалів : монографія / Л.Л. Брагіна, О.В. Саввова, О.В. Бабіч, Ю.О. Соболь. - Х. : ООО «Компанія СМІТ. - 2016. - 253 с.

3. Ромашин, А.Г. Радиопрозрачные обтекатели летательных аппаратов. Проектирование, конструкционные материалы, технология производства, испытания: учеб. пос. / А. Г. Ромашин, В. Е. Гайдачук, Я. С. Карпов, М. Ю. Русин. - Харьков: Нац. аэрокосм. ун-т «Харьк. авиац. ин-т». - 2003. - 239 с.

4. Пат. 2513389, РФ, МПК ${ }^{6}$ С 04 В 35/19, С 04
В 33/28. Способ изготовления антенного обтекателя из стеклокерамики литийалюмосиликатного состава / Суздальцев Е. И., Харитонов Д. В., Русин М.Ю., Зайчук Т. В., Ермолаев А. С.; заявитель и патентообладатель Федер. гос. унитарн. предприятие «Обнинск. науч. - произв. предприятие «Технология». - № 2013105364/03; заявл. 07.02.2013; опубл. 20.04.2014, Бюл. № 11 - 8 c.

5. Павлушкин, Н.М. Химическая технология стекла и ситаллов. - Москва : Стройиздат. - 1983. -431 с. 6. V. K. Marghussian, M.J. Geramian Fabrication of cordierite glass ceramics by slip casting of glass powders British Ceramic Transactions. 2013. - Vol. 98. - No. 3. - P. 133 - 140. https://doi. org/10.1179/096797899680345.

7. Frank Clemens Thermoplastic Extrusion for Ceramic Bodies / In: Händle F. (eds) Extrusion in Ceramics. Engineering Materials and Processes. Springer, Berlin, Heidelberg, - 2009 - P. 295 - 311, https://doi.org/10.1007/978-3-540-27102-4 17.

8. Пат. RU 2170715 C2, C03C 10/12, C04B 35/19. Способ получения изделий из спеченного стеклокристаллического материала литийалюмосиликатного состава / Суздальцев Е.И. (RU), Суслова M.A. (RU), Балакина Л.И. (RU), Ипатова Н.И. (RU), Викулин В.B. (RU), Русин М.Ю. (RU), Хамицаев A.C. (RU) // Обнинское научно-производственное предприятие «Технология» заявл. 27.09.1999, опубл. 20.07.2001.

9. Придатко, Ю.М., Королев, Л.В., Готовиев, В.М. Моделирование плотной упаковки частиц композитного материала / Вестник СГТУ. Саратов. - 2011. - № 4(62). - C. 96 - 100.

10. Savvova, O., Babich, O., Voronov, G., Ryabinin, S. High-strength spodumene glass-ceramic materials / Strength of materials. - 2017. - Vol. 49, № 3. - P. 488 495. https://doi.org/10.1007/s11223-017-9890-4.

11. Пат. RU 2366637 C1, C04B 35/19, C04B 33/28. Способ получения высокоплотных водных шликеров на основе литийалюмосиликатного стекла / Суздальцев Е. И. (RU), Русин М. Ю. (RU), Харитонов Д. В. (RU), Зайчук Т. В. (RU), Ипатова Н. И. (RU) // Обнинское научно-производственное предприятие «Технология» заявл. 25.01.2008, опубл. 10.09.2009.

12. Алексенцева, С.Е. Влияние демпфирующих свойств сплавов на пулестойкость / С.Е. Алексенцева, И.В. Захаров // Вестник СамГТУ. Серия «Технические науки». - 2011. - № 4(32). - С. 88 - 95. 13. Алексенщева, C.E. Ударно-волновые процессы взаимодействия высокоскоростных элементов с конденсированными средами: дис. доктора тех. наук : 01.04.17 / Алексенцева Светлана Евгеньевна. Самара. - 2015. - 173 c. 